\title{
UJI DAYA HAMBAT ASAP CAIR TEMPURUNG KELAPA (Cocos nucifera L.) TERHADAP PERTUMBUHAN Escherichia coli SECARA IN VITRO
}

\section{THE TEST OF THE INHIBITION OF COCONUT SHELL LIQUID SMOKE (Cocos nucifera L.) ON THE GROWTH OF Escherichia coli IN VITRO}

\author{
Rachel Daniella Dinda Maria Lumban Tobing ${ }^{1}$, Made Ria Defiani ${ }^{1}$, Ni Made Susun Parwanayoni ${ }^{1}$ \\ ${ }^{1}$ Program Studi Biologi Fakultas Matematika dan Ilmu Pengetahuan Alam Universitas Udayana \\ Bukit Jimbaran \\ Email : racheldaniella08@yahoo.com
}

ABSTRAK

Daging yang terkontaminasi bakteri berpotensi menimbulkan penyakit yang berbahaya apabila dikonsumsi manusia. Salah satu kuman khususnya bakteri yang mencemari daging baik yang mentah atau daging dengan proses pematangan yang kurang sempurna adalah Escherichia coli. Oleh sebab itu, E. coli perlu diminimalisir dengan cara menghambat pertumbuhannya. Salah satu cara alami untuk menghambat pertumbuhan E. coli adalah dengan uji antibakteri menggunakan asap cair. Asap cair dapat diperoleh melalui proses pirolisis dari berbagai biomassa yang mengandung selulosa, hemiselulosa, dan lignin seperti pada tempurung kelapa (Cocos nucifera L.). Asap cair mengandung senyawa fenol dan asam yang bersifat antimikroba dan antioksidan. Penelitian ini menggunakan metode sumur difusi. Analisis data menggunakan Rancangan Acak Lengkap (RAL) dengan uji ragam (ANOVA) apabila data memiliki beda nyata pada taraf uji 5\% ( $\mathrm{P} \leq 5)$ maka dilanjutjan uji Duncan. Asap cair tempurung kelapa mampu menghambat pertumbuhan E.coli yang ditandai dengan terbentuknya zona hambat. Konsentrasi asap cair tempurung kelapa yang efektif menghambat pertumbuhan E. coli adalah konsentrasi $50 \%$ dengan diameter zona hambat $16,66 \mathrm{~mm}$ dan $M I C$ pada konsentrasi $10 \%$ dengan diameter zona hambat 9,33 $\mathrm{mm}$. Hasil uji fitokimia asap cair tempurung kelapa positif mengandung senyawa fenol, flavonoid, triterpenoid, dan saponin serta kadar fenol 2,403\% dan kadar saponin 5,50\%.

Kata Kunci: asap cair tempurung kelapa, antibakteri, MIC, E. coli

\begin{abstract}
Meat contaminated with bacteria has the potential to cause dangerous diseases when consumed by humans. One of the germs, especially bacteria that contaminate raw meat or meat with an incomplete maturation process is Escherichia coli. Therefore, E. coli needs to be minimized by inhibiting its growth. One natural way to inhibit the growth of E. coli is to test for antibacterials using liquid smoke. Liquid smoke can be obtained through the pyrolysis process from various biomass containing cellulose, hemicellulose, and lignin such as coconut shell (Cocos nucifera L.). Liquid smoke contains phenolic and acid compounds which are antimicrobial and antioxidant. This research uses the diffusion well method. Data analysis used Completely Randomized Design (CRD) with variance test (ANOVA). If the data had a significant difference at the $5 \%$ test level $(\mathrm{P} \leq 5)$, the Duncan test was continued. Coconut shell liquid smoke is able to inhibit the growth of E. coli which is indicated by the formation of an inhibition zone. The concentration of coconut shell liquid smoke which effectively inhibited the growth of E. coli was a concentration of 50\% with an inhibition zone diameter of $16.66 \mathrm{~mm}$ and MIC at a concentration of $10 \%$ with an inhibition zone diameter of $9.33 \mathrm{~mm}$. Phytochemical test results of coconut shell liquid smoke contain positive phenolic compounds, flavonoids, triterpenoids, and saponins as well as phenol content of $2.403 \%$ and saponin content of $5.50 \%$.
\end{abstract}

Keywords: coconut shell liquid smoke, antibacterial, MIC, E. coli 


\section{PENDAHULUAN}

Negara Indonesia kaya akan sumber daya alam, salah satunya yaitu buah kelapa (Cocos nucifera L.). Hampir semua bagian dari buah kelapa telah dimanfaatkan, namun banyak pula yang terbuang sehingga menjadi sampah seperti bagian tempurungnya (Masthura dan Zulkarnain, 2018). Penggunaan hasil limbah hayati ini masih lebih aman digunakan untuk manusia jika dibandingkan bahan kimia/sintetis, karena efek samping dari penggunaan bahan tersebut sangat berbahaya bagi kesehatan manusia oleh residu dalam jangka panjang. Penggunaan senyawa alami dinilai lebih aman, sehat, dan tidak menimbulkan efek samping serta fungsinya untuk pencegahan dan juga pengobatan (Harini dan Wachid, 2012).

Sangat banyak sekali manfaat dari tanaman kelapa yang bisa dijadikan sebuah produk unggulan bernilai ekonomis tinggi. Mulai dari daging buah kelapa yang dimanfaatkan sebagai olahan kopra, minyak kelapa kasar (Crude Coconut Oil), dan VCO (Virgin Coconut Oil). Sabut kelapa sebagai produk serat sabut (cocofiber), serbuk sabut (cocopeat), cocopeat brick, cocomesh, cocopot, cocosheet, Coco Fiber Board (CFB), dan coco coir. Air kelapa untuk nata de coco. Tempurung kelapa untuk charcoal, karbon aktif, dan arang briket. Akar dan batang untuk peralatan rumah tangga dan lain-lain (Indahyani, 2011).

Asap cair merupakan suatu campuran dispersi asap kayu dalam air yang dibuat dengan mengkondensasikan asap hasil pembakaran kayu (Karseno dkk., 2002). Asap cair dipakai secara komersial sebagai bahan pemberi aroma pada ikan dan daging karena adanya komponen flavor dari senyawa-senyawa fenolik. Selain itu, asap cair telah banyak digunakan sebagai pengawet bahan pangan, kesehatan, dan pasca panen hasil pertanian. (Muratore and Licciardello, 2005). Asap cair dapat diperoleh melalui proses pirolisis dari berbagai biomassa yang mengandung selulosa, hemiselulosa, dan lignin seperti pada tempurung kelapa (Nasruddin, 2015).

Asap cair mengandung senyawa fenol dan asam yang bersifat antimikroba dan antioksidan (Jayanudin dkk., 2012). Menurut penelitian Zuraida dkk. (2009), asap cair tempurung kelapa mempunyai aktivitas antibakteri terhadap Pseudomonas aeruginosa dan Staphylococcus aureus yang mampu memperpanjang umur simpan bakso ikan selama 16 jam. Salah satu kuman khususnya bakteri yang mencemari daging baik yang mentah atau daging dengan proses pematangan yang kurang sempurna adalah Escherichia coli. Kontaminasi bakteri yang terjadi pada makanan ini dapat menyebabkan perubahan makanan tersebut menjadi media bagi suatu penyakit atau yang lebih dikenal dengan foodborne diseases (Nadifah dkk., 2014).

Bakteri E. coli yang terdapat pada makanan dan minuman yang masuk ke dalam tubuh manusia dapat menyebabkan gejala seperti diare, mual, muntah, dan penyakit seperti disentri, gastroenteritis, dan berbagai penyakit saluran pencernaan lainnya (Nurwanto, 2007). E. coli adalah salah satu jenis spesies utama bakteri Gram negatif yang menyebabkan infeksi saluran pencernaan (Sutiknowati, 2016). Bakteri ini ditemukan di dalam usus manusia yang berperan dalam proses pengeluaran zat sisa pada saluran pencernaan dan dapat menginfeksi usus sehingga menimbulkan diare (Puteri dan Milanda 2017). Pertumbuhan bakteri penyebab infeksi dan penyakit perlu dihambat dengan antibakteri. Antibakteri merupakan zat yang dapat menghambat pertumbuhan bakteri dan dapat membunuh bakteri patogen (Paju dkk., 2013). Berdasarkan hal tersebut untuk meningkatkan potensi asap cair tempurung kelapa sebagai senyawa antimikroba, maka perlu dilakukan penelitian tentang uji aktivitas antibakteri yang dapat menghambat pertumbuhan E. coli. 


\section{METODE PENELITIAN}

\section{Waktu dan Tempat Penelitian}

Penelitian dilakukan pada bulan Januari-Februari 2021 di Laboratorium Teknologi Pakan, Balai Penelitian Ternak yang beralamat di Jl. Veteran III, Desa Banjarwaru, Kecamatan Ciawi, Kabupaten Bogor, Jawa Barat.

\section{Rancangan Percobaan}

Metode yang digunakan untuk uji MIC dalam penelitian ini adalah metode eksperimen dengan menggunakan Rancangan Acak Lengkap (RAL) yang terdiri dari konsentrasi asap cair tempurung kelapa $0 \%(\mathrm{v} / \mathrm{v}) ; 0,1 \%(\mathrm{v} / \mathrm{v}) ; 0,5 \%(\mathrm{v} / \mathrm{v})$; $1 \% \quad(\mathrm{v} / \mathrm{v}) ; 1,5 \% \quad(\mathrm{v} / \mathrm{v}) ; 2 \% \quad(\mathrm{v} / \mathrm{v}) ; 2,5 \%$ $(\mathrm{v} / \mathrm{v}) ; 3 \%(\mathrm{v} / \mathrm{v}) ; 4 \%(\mathrm{v} / \mathrm{v}) ;$ dan $5 \%(\mathrm{v} / \mathrm{v})$ yang diulang sebanyak 3 kali sehingga diperoleh 30 unit percobaan (Tabel 1).

Kemudian untuk uji aktivitas antibakteri asap cair tempurung kelapa menggunakan Rancangan Acak Lengkap (RAL) yang terdiri dari konsentrasi asap cair tempurung kelapa $0 \% ; 5 \%(\mathrm{v} / \mathrm{v}) ; 10 \%$ $(\mathrm{v} / \mathrm{v}) ; 15 \%(\mathrm{v} / \mathrm{v}) ; 20 \%(\mathrm{v} / \mathrm{v}) ; 25 \%(\mathrm{v} / \mathrm{v})$; $30 \% \quad(\mathrm{v} / \mathrm{v}) ; 35 \%(\mathrm{v} / \mathrm{v}) ; 40 \%(\mathrm{v} / \mathrm{v}) ; 45 \%$ $(\mathrm{v} / \mathrm{v}) ;$ dan $50 \% \quad(\mathrm{v} / \mathrm{v})$ yang diulang sebanyak 3 kali sehingga diperoleh 33 unit percobaan (Tabel 2).

Rancangan penelitian dibuat untuk mengetahui MIC dan daya hambat aktivitas antibakteri dari asap cair tempurung kelapa terhadap pertumbuhan E. coli. Pengenceran konsentrasi asap cair tempurung kelapa dilakukan dengan rumus sebagai berikut (Laia dkk., 2019):

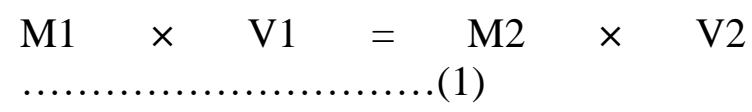

Keterangan:

M1 = Molaritas sebelum pengenceran

M2 = Molaritas setelah pengenceran

V1 = Volume sebelum pengenceran

V2 = Volume setelah pengenceran
Tabel 1. Perlakuan MIC asap cair tempurung kelapa

\begin{tabular}{cc}
\hline Perlakuan & $\begin{array}{c}\text { Persentase } \\
(\%)\end{array}$ \\
\hline M1 & 0 \\
M2 & 0,1 \\
M3 & 0,5 \\
M4 & 1 \\
M5 & 1,5 \\
M6 & 2 \\
M7 & 2,5 \\
M8 & 3 \\
M9 & 4 \\
M10 & 5 \\
\hline
\end{tabular}

Tabel 2. Perlakuan aktivitas antibakteri asap cair tempurung kelapa

\begin{tabular}{cc}
\hline Perlakuan & Persentase $\mathbf{\%})$ \\
\hline T1 & 0 \\
T2 & 5 \\
T3 & 10 \\
T4 & 15 \\
T5 & 20 \\
T6 & 25 \\
T7 & 30 \\
T8 & 35 \\
T9 & 40 \\
T10 & 45 \\
T11 & 50 \\
\hline
\end{tabular}

\section{Pirolis Asap Cair Tempurung Kelapa}

Pirolisis asap cair tempurung kelapa dilakukan di rumah industri Cinangneng, Bogor. Tempurung kelapa dibersihkan, lalu dipotong atau dipecahkan menjadi beberapa bagian. Selanjutnya dilakukan proses pirolisis pada suhu $150-300^{\circ} \mathrm{C}$ di dalam reaktor pirolisator selama 8 jam pembakaran. Komponen tempurung kelapa akan terkondensasi membentuk produk cair dan gas, asap cair hasil kondensasi dialirkan melalui pipa kaca dan ditampung ke dalam sebuah wadah. Sedangkan air pendingin dialirkan di bagian luar pipa kaca menggunakan sebuah pompa air. Wadah yang sudah berisi asap cair didiamkan selama 24 jam 
dan akan terbentuk 2 produk yaitu endapan dan asap cair grade 2. Asap cair grade 2 ini akan digunakan untuk uji aktivitas antibakteri (Slamet dan Hidayat, 2015).

\section{Pembuatan media dan kultur bakteri}

Media yang digunakan dalam uji antimikroba adalah Nutrient Agar (NA) dan larutan $\mathrm{NaCl}$ fisiologis $0,98 \%$. Pembuatan media NA yaitu 7 g NA dilarutkan dalam $250 \mathrm{~mL}$ akuades. Kemudian media NA disterilisasi dengan autoclave, media NA yang sudah steril dituang ke dalam cawan Petri dan didiamkan hingga membeku. Pembuatan larutan $\mathrm{NaCl}$ fisiologis $0,98 \%$ yaitu $2,45 \mathrm{~g}$ $\mathrm{NaCl}$ dilarutkan dalam $250 \mathrm{~mL}$ akuades. Larutan $\mathrm{NaCl}$ fisiologis $0,98 \%$ kemudian disterilisasi dengan autoclave. Biakan bakteri E. coli diregenerasi dengan menginokulasikan 1 ose biakan murni bakteri dan disuspensikan ke dalam $5 \mathrm{~mL}$ larutan $\mathrm{NaCl}$ fisiologis $0,98 \%$. Lalu dihitung kekeruhannya menggunakan standar 0,5 McFarland atau setara dengan jumlah bakteri $1,5 \times 10^{8} \mathrm{CFU} / \mathrm{mL}$. Inokulasi bakteri dilakukan dengan metode spread plate. Selanjutnya biakan bakteri dapat digunakan untuk uji aktivitas antibakteri (Wahyuningsih, 2017).

\section{Uji MIC dan aktivitas antibakteri dengan metode sumur difusi}

Media NA yang sudah diinokulasikan bakteri kemudian dibuat lubang atau sumur yang berdiameter $6 \mathrm{~mm}$ dengan menggunakan cork borer. Setiap cawan Petri berisi 3 lubang sebagai ulangan. Cawan Petri yang sudah dilubangi, akan diisi kontrol positif (Chloramphenicol), kontrol negatif (akuades), dan asap cair tempurung kelapa menggunakan mikropipet. Kontrol positif menggunakaan Chloramphenicol, yaitu Chloramphenicol sebanyak 0,01 g dilarutkan ke dalam 20 $\mathrm{mL}$ aquades. Plate diinkubasi pada suhu $37^{\circ} \mathrm{C}$ selama 24 jam. Zona bening yang terbentuk di sekitar sumur menunjukkan uji positif yaitu adanya aktivitas antibakteri. Diameter zona bening yang diperoleh, diukur menggunakan mistar (Mpila dkk., 2012).

\section{Uji fitokimia}

\section{Uji fitokimia secara kualitatif}

Golongan senyawa dari komponen aktif yang diuji meliputi:

a. Golongan senyawa fenol dengan pereaksi $\mathrm{FeCl}_{3}$, satu $\mathrm{mL}$ sampel ditetesi pereaksi $\mathrm{FeCl}_{3}$, reaksi positif apabila terjadi perubahan warna dari hijau kecoklatan menjadi biru hitam (Manongko dkk., 2020).

b. Golongan senyawa alkaloid dengan pereaksi Wagner, satu $\mathrm{mL}$ sampel ditambahkan beberapa tetes pereaksi Wagner, reaksi positif apabila terbentuk endapan coklat (Djoronga dkk., 2014).

c. Golongan senyawa flavonoid dengan pereaksi $\mathrm{NaOH} 10 \%$, satu $\mathrm{mL}$ sampel ditambahkan tetes demi tetes pereaksi $\mathrm{NaOH} 10 \%$. Reaksi positif jika ada perubahan warna kuning menjadi merah (Ikalinus dkk., 2015).

d. Golongan senyawa triterpenoid/steroid dengan pereaksi Lieberman-Burchard, satu $\mathrm{mL}$ sampel ditetesi pereaksi Lieberman-Burchard, jika terjadi perubahan warna dari kuning menjadi ungu positif triterpenoid, sedangkan perubahan warna menjadi biru positif steroid (Ikalinus dkk., 2015).

e. Golongan saponin dengan uji biasa, 3 mL sampel dicampur dengan air panas selanjutnya dikocok, adanya saponin ditandai dengan terbentuknya busa yang stabil pada permukaan cairan (Lisi dkk., 2017).

\section{Uji fitokimia secara kuantitatif kadar fenol}

Asap cair tempurung kelapa diencerkan menggunakan aquades. Kemudian diambil 0,5 mL sampel yang sudah diencerkan, ditambah $0,25 \mathrm{~mL}$ folin ciocalteu dan 1,25 $\mathrm{Na}_{2} \mathrm{CO}_{3} \quad 20 \%$, selanjutnya dihomogenkan menggunakan vortex mixer, dan didiamkan selama 40 
menit. Setelah 40 menit, sampel diukur absorbansinya dalam spektrofotometer dengan panjang gelombang 765 nm (Putri dkk., 2018). Hasil absorbansi akan dimasukkan ke dalam perhitungan. Septiani dkk. (2017) menyatakan perhitungan kadar fenol dimasukkan ke dalam rumus sebagai berikut:

$\%$ Fenol $(\mathrm{v} / \mathrm{v})=\frac{\frac{\mathrm{y}-\mathrm{a}}{\mathrm{b}} \times \text { faltor pengencer }}{(1000 \times 10)}$

Keterangan:

$\mathrm{y} \quad=$ absorbansi

$a$ dan $b=$ regresi linier

\section{Uji fitokimia secara kuantitatif kadar saponin}

Penentuan kadar saponin dilakukan menurut prosedur Pasaribu et al. (2014) yang dimodifikasi. Asap cair tempurung kelapa diencerkan menggunakan akuades. Kemudian diambil 0,5 $\mathrm{mL}$ sampel yang sudah diencerkan, ditambah $0,25 \mathrm{~mL}$ vanillin dan $2,5 \quad \mathrm{~mL} \quad \mathrm{H}_{2} \mathrm{SO}_{4} \quad 72 \%$, selanjutnya dihomogenkan menggunakan vortex mixer. Sampel dimasukkan ke dalam water bath dengan suhu $60^{\circ} \mathrm{C}$ selama 10 menit. Setelah 10 menit, sampel didiamkan hingga dingin. Sampel diukur absorbansinya dalam spektrofotometer dengan panjang gelombang $544 \mathrm{~nm}$. Hasil absorbansi akan dimasukkan ke dalam perhitungan. Menurut Pasaribu et al. (2014), perhitungan kadar saponin dimasukkan ke dalam rumus sebagai berikut:

$\%$ Saponin $(\mathrm{v} / \mathrm{v})=\frac{\frac{\mathrm{y}-\mathrm{a}}{\mathrm{b}} \times \text { faktor pengencer }}{10}$

Keterangan:

$\mathrm{y} \quad=$ absorbansi

$a$ dan $b=$ regresi linier

\section{Metode Pengolahan Data}

Data yang diperoleh dianalisis secara kuantitatif menggunakan Analysis of Varians (ANOVA) pada taraf 5\%, dan dilanjutkan dengan uji Duncans pada taraf
5\% apabila terdapat perbedaan pengaruh yang nyata. Data dianalisis dengan menggunakan program Statistical Analysis System (SAS) Series 9.

\section{HASIL DAN PEMBAHASAN Hasil}

Hasil penelitian menunjukkan bahwa Minimum Inhibitory Concentration (MIC) asap cair tempurung kelapa adalah pada konsentrasi $10 \%$ dengan diameter zona hambat 9,33 $\mathrm{mm}$ (Tabel 3 dan Gambar 2). Sedangkan pada konsentrasi $0,1 \%, 0,5 \%, 1 \%, 1,5 \%, 2 \%, 2,5 \%, 3 \%$, $4 \%, 5 \%$ tidak terlihat adanya zona hambat yang terbentuk di sekitar sumuran, dan kontrol positif yaitu Chloramphenicol dengan dosis 500 ppm diameter zona hambatnya adalah 35,66 mm (Gambar 1). Tabel 3. Zona hambat MIC asap cair tempurung kelapa terhadap pertumbuhan E. coli

\begin{tabular}{|c|c|}
\hline Konsentrasi (\%) & $\begin{array}{l}\text { Diameter zona } \\
\text { hambat (mm) }\end{array}$ \\
\hline $\begin{array}{c}\text { Kontrol positif } \\
\text { (Chloramphenicol } 500\end{array}$ & \\
\hline ppm) & $35,66^{\mathrm{a}} \pm 0,58$ \\
\hline Kontrol negatif & \\
\hline (Akuades) & $0^{\mathrm{c}}$ \\
\hline 10 & $9,33^{\mathrm{b}} \pm 0,58$ \\
\hline 5 & $0^{c}$ \\
\hline 4 & $0^{c}$ \\
\hline 3 & $0^{c}$ \\
\hline 2,5 & $0^{c}$ \\
\hline 2 & $0^{c}$ \\
\hline $\mathrm{v} 1,5$ & $0^{c}$ \\
\hline 1 & $0^{c}$ \\
\hline 0,5 & $0^{c}$ \\
\hline 0,1 & $0^{\mathrm{c}}$ \\
\hline
\end{tabular}

Keterangan: Nilai rata-rata yang diikuti dengan notasi huruf yang berbeda pada kolom yang berbeda menunjukkan hasil yang tidak berbeda nyata pada taraf uji 5\% (P > 0,05)

Hasil uji daya hambat asap cair tempurung kelapa terhadap E. coli diperoleh bahwa asap cair tempurung kelapa mampu menghambat pertumbuhan dari bakteri $E$. coli yang dibuktikan dengan adanya zona hambat yang terbentuk di sekitar sumuran (Gambar 2). Berdasarkan hasil analisis statistik, rata-rata zona 
hambat pada semua konsentrasi 5\%, 10\%, $15 \%, 20 \%, 25 \%, 30 \%, 35 \%, 40 \%, 45 \%$, dan $50 \%$ asap cair tempurung kelapa terhadap E. coli menunjukkan hasil yang signifikan pada taraf uji 5\% (P<0,05) (Tabel 4). Semakin meningkatnya konsentrasi, maka kemampuan asap cair tempurung kelapa semakin meningkat dalam menghambat pertumbuhan bakteri

E.coli.
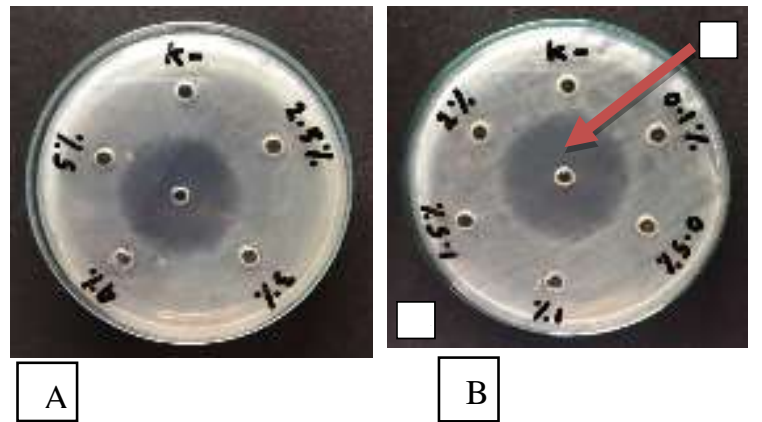

Gambar 1. (A) $M I C$ asap cair tempurung kelapa terhadap pertumbuhan E.coli pada konsentrasi $0,1 \%, 0,5 \%, 1 \%, 1,5 \%$, dan $2 \%$

(B) $M I C$ asap cair tempurung kelapa terhadap pertumbuhan E.coli pada konsentrasi 2,5\%, 3\%, $4 \%$, dan $5 \%$

Keterangan: (a) Kontrol positif Chloramphenicol

Tabel 4. Zona hambat aktivitas antibakteri asap cair tempurung kelapa terhadap pertumbuhan E. coli

\begin{tabular}{cc}
\hline Konsentrasi (\%) & Zona hambat $(\mathbf{m m})$ \\
\hline Kontrol positif & $35,66^{\mathrm{a}} \pm 0,58$ \\
(Chloramphenicol $500 \mathrm{ppm})$ & $0^{\mathrm{h}}$ \\
Kontrol negatif (Akuades) & $0^{\mathrm{h}}$ \\
5 & $9,33^{\mathrm{g}} \pm 0,58$ \\
10 & $9,66^{\mathrm{g}} \pm 0,58$ \\
15 & $10,33^{\mathrm{gf}} \pm 0,58$ \\
20 & $11^{\mathrm{f}} \pm 0$ \\
25 & $12,33^{\mathrm{e}} \pm 0,58$ \\
30 & $13^{\mathrm{ed}} \pm 1$ \\
35 & $13,66^{\mathrm{d}} \pm 0,58$ \\
40 & $15,33^{\mathrm{c}} \pm 0,58$ \\
45 & $16,66^{\mathrm{b}} \pm 0,58$ \\
50 &
\end{tabular}

Keterangan: Nilai rata-rata yang diikuti dengan notasi huruf yang berbeda pada kolom yang berbeda menunjukkan hasil yang berbeda nyata pada taraf uji $5 \%(\mathrm{P}<0,05)$

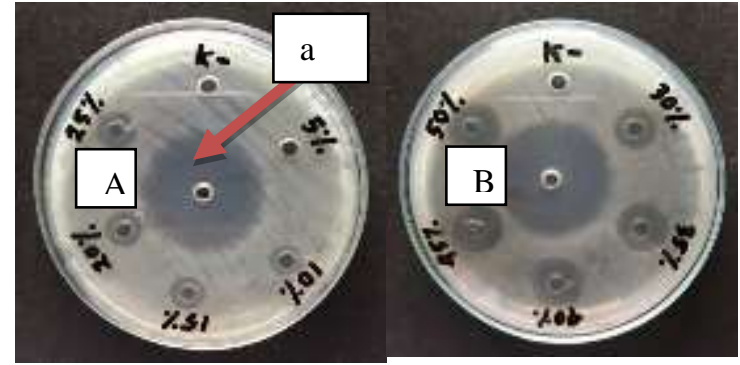

Gambar 2. (A) Aktivitas antibakteri asap cair tempurung kelapa terhadap pertumbuhan E. coli pada konsentrasi 5\%, 10\%, 15\%, 20\%, dan $25 \%$ (A) Aktivitas antibakteri asap cair tempurung kelapa terhadap pertumbuhan

E. coli pada konsentrasi 30\%, 35\%, 40\%, 45\%, dan $50 \%$

Keterangan: (a) Kontrol positif Chloramphenicol

Hasil uji fitokimia secara kualitatif asap cair tempurung kelapa menunjukkan bahwa asap cair tempurung kelapa mengandung senyawa fenol, flavonoid, triterpenoid, dan saponin. Namun, untuk hasil pengujian golongan senyawa alkaloid menunjukkan hasil negatif (Tabel 5) dan (Gambar 3).

Tabel 5. Hasil uji fitokimia secara kualitatif asap cair tempurung kelapa

\begin{tabular}{ccc}
\hline $\begin{array}{c}\text { Uji golongan } \\
\text { senyawa }\end{array}$ & $\begin{array}{c}\text { Hasil } \\
\text { uji }\end{array}$ & $\begin{array}{c}\text { Perubahan } \\
\text { yang terjadi }\end{array}$ \\
\hline Fenol & + & $\begin{array}{c}\text { Terbentuknya } \\
\text { warna hitam }\end{array}$ \\
Alkaloid & - & - \\
Flavonoid & + & $\begin{array}{c}\text { Terbentuknya } \\
\text { warna merah } \\
\text { tua }\end{array}$ \\
Triterpenoid/steroid & + & $\begin{array}{c}\text { Terbentuknya } \\
\text { warna jingga } \\
\text { Saponin }\end{array}$ \\
& + & $\begin{array}{c}\text { Terbentuknya } \\
\text { busa }\end{array}$ \\
\hline
\end{tabular}
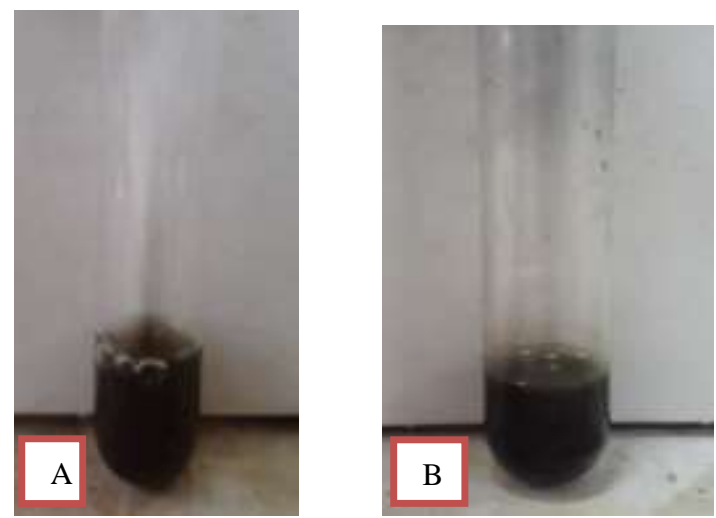

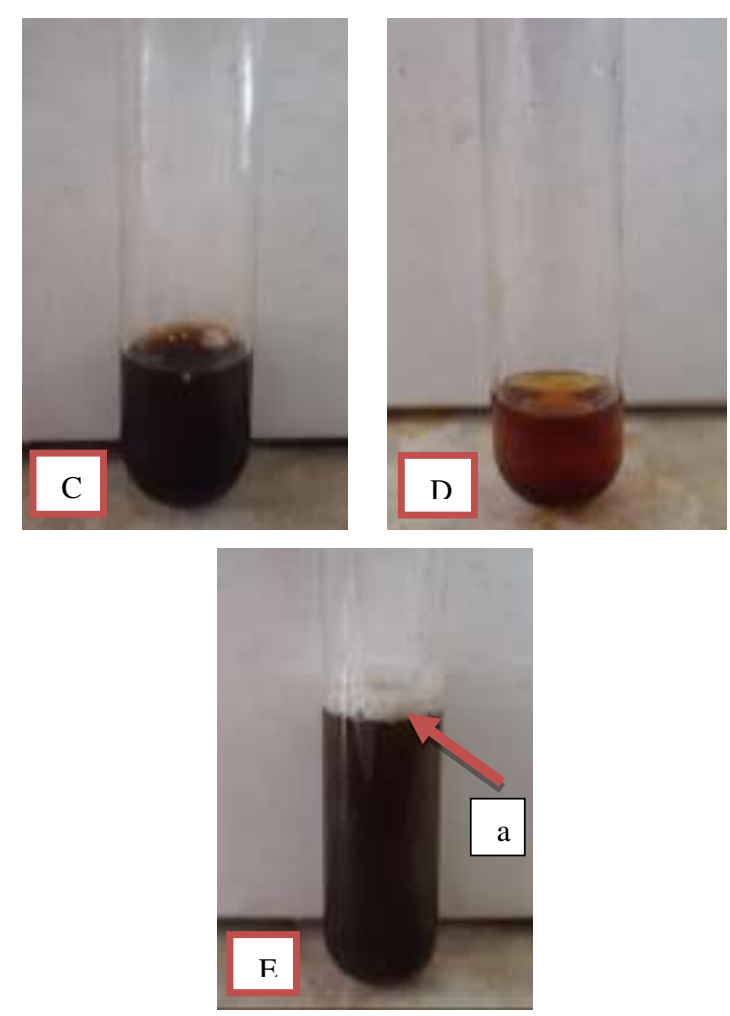

Gambar 3. Hasil uji fitokimia secara kualitatif asap cair tempurung kelapa (C. nucifera L.) fenol (A), alkaloid (B), flavonoid (C), triterpenoid (D), saponin (E)

Keterangan: (a) Busa

Hasil kadar fenol asap cair tempurung kelapa pada penelitian ini diperoleh yaitu $2,403 \%$ dan kadar saponin diperoleh $5,50 \%$ yang dapat dilihat pada Tabel 6 .

Tabel 6. Kadar fenol dan saponin asap cair tempurung kelapa

\begin{tabular}{ccc}
\hline Ulangan & $\begin{array}{c}\text { Kadar Fenol } \\
(\boldsymbol{\%})\end{array}$ & $\begin{array}{c}\text { Kadar } \\
\text { Saponin }(\%)\end{array}$ \\
\hline 1 & 2,317 & 5,60 \\
2 & 2,564 & 5,35 \\
3 & 2,330 & 5,51 \\
Rataan & 2,403 & 5,50 \\
\hline
\end{tabular}

\section{PEMBAHASAN}

MIC pada penelitian ini yaitu $10 \%$ dengan diameter zona hambat $9,33 \mathrm{~mm}$. Konsentrasi terendah yang dapat menghambat pertumbuhan bakteri disebut dengan MIC (Minimum Inhibitory Concentration) (Soleha, 2015). Pada Tabel
3 terlihat bahwa asap cair tempurung kelapa pada konsentrasi rendah belum mampu mengganggu metabolisme bakteri E. coli sehingga masih terdapat pertumbuhan bakteri di sekitar sumuran. Hal ini diduga karena kandungan senyawa yang berpotensi sebagai antibakteri pada asap cair tersebut hanya sedikit, sehingga kemampuan untuk menghambat pertumbuhan bakteri masih sangat lemah. Efektivitas yang rendah disebabkan karena pada konsentrasi tersebut jumlah asap cair yang digunakan sedikit sehingga senyawa aktif yang terkandung tidak bekerja secara maksimal. Efektivitas yang masih rendah menandakan bahwa kadar senyawa aktif sebagai antibakteri pada asap cair tempurung kelapa yang digunakan masih rendah (Oroh dkk., 2015).

Berdasarkan Tabel 4 terlihat bahwa diameter zona hambat paling tinggi dari asap cair tempurung kelapa yaitu pada konsentrasi $50 \%$ sebesar 16,66 $\mathrm{mm}$. Faktor-faktor yang mempengaruhi timbulnya zona hambat berupa kemampuan difusi bahan antimikroba ke dalam media dan interaksinya dengan mikroba yang diuji, jumlah mikroba yang diujikan, kecepatan tumbuh mikroba uji, dan tingkat sensitifitas mikroba terhadap bahan antimikroba (Muzafri, 2019). Dalam hal ini asap cair tempurung kelapa mampu berdifusi ke dalam media dan ke $E$. coli tersebut. Pada saat asap cair berdifusi ke dalam E. coli maka diduga terjadi kerusakan pada dinding ataupun inti sel dari E. coli, dengan demikian E. coli tidak dapat berkembang sehingga pertumbuhan E. coli terhambat. Diameter zona hambat cenderung meningkat sebanding dengan meningkatnya konsentrasi dalam perlakuan (Dewi dkk., 2013).

Kerusakan bakteri merupakan hasil interaksi senyawa antibakteri dengan bagian tertentu pada sel bakteri (Gilbert, 1984). Interaksi senyawa antibakteri tersebut dapat menyebabkan sejumlah perubahan atau kerusakan pada sel bakteri yang berpengaruh pada pola inaktivasi bakteri. Pada dosis yang tidak mematikan, 
bakteri akan mengalami luka, terjadi sejumlah perubahan dan kerusakan struktur sel bakteri yang akhirnya dapat mempengaruhi fungsi metabolisme sel. Sedangkan pada dosis yang tinggi akan mengalami kerusakan yang parah dan menyebabkan kematian. Perubahan dan kerusakan struktur sel oleh senyawa antibakteri dapat berupa perubahan morfologi sel, perubahan sturktur sel, ukuran sel, kebocoran dinding dan membran sel, ketebalan dinding, dan penampakan sitoplasma (Gemmel and Lorian, 1996).

Chloramphenicol bekerja pada spektrum luas sehingga efektif terhadap bakteri Gram positif maupun Gram negatif (Kar, 2005). Chloramphenicol menunjukkan adanya zona hambat yang mengindikasikan bahwa kontrol yang digunakan berpengaruh pada uji antibakteri. Chloramphenicol merupakan antibiotik yang mempunyai aktivitas bakteriostatik dan pada dosis tinggi bersifat bakterisidal. Aktivitasnya menghambat sintesis protein dengan jalan mengikat ribosom yang merupakan langkah penting dalam pembentukan ikatan peptida (Dian dkk., 2015).

Berdasarkan hasil penelitian, diameter zona hambat antibiotik Chloramphenicol adalah 35,66 mm dan termasuk kategori kuat. Antibiotik Chloramphenicol akan melekat pada subunit 50s ribosom bakteri sehingga menghalangi enzim Peptidiltransferase. Enzim inilah yang melaksanakan 3 langkah dengan membentuk ikatan peptida antara asam amino baru yang masih melekat pada tRNA-nya, dan asam amino terakhir peptida yang sedang berkembang. Hal ini menyebabkan sintesis protein terhenti seketika. Bila tidak terjadi perubahan struktur purin oleh bakteri maka sensitifitasnya tidak akan berkurang. Purin merupakan tempat masuknya antibiotik agar antibiotik dapat bekerja pada dinding sitenya. Struktur purin yang tetap pada dinding sel bakteri menyebabkan bakteri. E. coli masih sensitif terhadap antibiotik
Chloramphenicol (Goodman dan Gilman, 2007).

Kriteria kekuatan antibakteri berdasarkan diameter zona hambat yaitu lemah (5-10 mm), kuat (10-20 mm), dan sangat kuat (>20 mm) (Fiana dkk., 2020). Berdasarkan kriteria kekuatan antibakteri tersebut, maka daya hambat aktivitas antibakteri asap cair tempurung kelapa terhadap bakteri $E$. coli dengan konsentrasi $5 \%$ termasuk lemah, konsentrasi $10 \%$, $15 \%, 20 \%$ termasuk sedang, serta konsentrasi 25\%, 30\%, 35\%, 40\%, 45\%, dan $50 \%$ termasuk kuat. E. coli termasuk ke dalam bakteri Gram negatif yang memiliki lapisan peptidoglikan tipis dalam menyusun dinding sel bakteri, sehingga dinding selnya mudah rusak. Peptidoglikan merupakan komponen yang digunakan untuk mempertahankan keutuhan sel. Karena sedikit dan tipisnya lapisan peptidogilkan serta tidak adanya kandungan asam teikoat yang menyusun dinding sel bakteri Gram negatif menyebabkan dinding selnya lebih rentan mengalami kerusakan ketika diberikan antibakteri (Radji, 2011). Perbedaan diameter zona bening dapat dipengaruhi oleh tingkat sensitifitas dari organisme uji, medium kultur dan kondisi inkubasi, kecepatan difusi dari senyawa antibakteri, dan konsentrasi senyawa antibakteri (Sari dkk., 2014).

Zona hambatan yang terbentuk memiliki ukuran yang berbeda pada masing-masing konsentrasi. Semakin kecil konsentrasi, semakin sedikit jumlah zat aktif yang terlarut di dalamnya, sehingga semakin rendah kemampuannya dalam menghambat pertumbuhan $E$. coli dan semakin tinggi konsentrasi maka semakin banyak bahan aktif yang berfungsi sebagai antibakteri, sehingga kemampuan dalam menghambat pertumbuhan bakteri juga semakin besar (Schlegel dan Schmidt, 1994). Konsentrasi antimikroba yang rendah umumnya akan bersifat bakteriostatik, sedangkan konsentrasi tinggi akan bersifat bakterisida (Bakti dkk., 2002). Zona hambat asap cair 
tempurung kelapa lebih kecil daripada zona hambat kontrol positif Chloramphenicol, sedangkan akuades sebagai kontrol negatif tidak terbentuk zona hambat. Hal ini membuktikan bahwa akuades tidak berpengaruh pada pembentukan zona hambat di sekitar sumur.

Berdasarkan hasil pada Tabel 5 dan Gambar 3 yaitu uji senyawa alkaloid yang terdapat pada asap cair tempurung kelapa menunjukkan tidak teridentifikasi senyawa alkaloid. Menurut Djoronga dkk. (2014), pengujian senyawa alkaloid dilakukan dengan menggunakan metode Wagner yaitu apabila positif mengandung alkaloid akan terdapat endapan yang berwarna coklat hingga warna kuning. Pada saat penelitian hasil tidak teridentifikasi atau tidak mengalami perubahan. Hal ini terjadi dikarenakan pemilihan metode yang kurang tepat dalam melakukan analisis fitokimia senyawa alkaloid. Mekanisme alkaloid menurut Amalia dkk. (2017), dengan cara mengganggu komponen penyusun peptidoglikan pada sel bakteri sehingga lapisan dinding sel tidak terbentuk secara utuh dan menyebabkan terjadinya kematian sel. Pada hasil uji fitokimia, terdapat senyawa fenol pada asap cair tempurung kelapa. Sampel mengandung senyawa fenol ditunjukkan dengan terbentuknya warna hijau kehitaman (Manongko dkk., 2020).

Sebagai antibakteri, senyawa fenol memiliki mekanisme kerja dengan merusak struktur sel bakteri dan menghambat proses pembentukan dinding sel sehingga dapat menyebabkan lisis pada dinding sel bakteri (Susanti, 2006). Selain itu, reaksi dengan membran sel yang menyebabkan meningkatnya permeabilitas membran sel dan mengakibatkan hilangnya isi sel, inaktivasi enzim-enzim esensial, serta perusakan atau inaktivasi fungsional materi genetik. Semakin tinggi konsentrasi fenol akan semakin mengendapkan semua protein sel, sebaliknya semakin rendah konsentrasinya akan semakin menghambat enzim-enzim esensial secara efektif (Davidson et al., 2005).

Uji fitokimia flavonoid menunjukkan hasil positif dengan adanya perubahan warna merah tua. Mekanisme terhadap antibakteri yaitu dengan menghambat fungsi membran sel dan metabolisme energi bakteri. Saat menghambat fungsi membran sel, flavonoid membentuk senyawa kompleks dengan protein ekstraseluler yang dapat merusak membran sel bakteri E. coli, lalu diikuti dengan keluarnya senyawa intraseluler bakteri tersebut (Nuria dkk., 2009).

Pada uji triterpenoid menghasilkan positif yang ditandai dengan perubahan warna jingga. Mekanisme kerja senyawa triterpenoid sebagai antibakteri adalah bereaksi dengan porin (protein transmembran) pada membran luar dinding sel bakteri dan membentuk ikatan polimer yang kuat sehingga mengakibatkan rusaknya porin. Rusaknya porin yang merupakan pintu keluar masuknya senyawa akan mengurangi permeabilitas dinding sel bakteri dan mengakibatkan sel bakteri akan kekurangan nutrisi, sehingga pertumbuhan bakteri terhambat atau mati (Anggraini dkk., 2019).

Uji fitokimia senyawa saponin yang dilakukan diketahui hasil bahwa asap cair tempurung kelapa positif mengandung senyawa saponin yang ditandai dengan terbentuknya busa. Mekanisme kerja saponin sebagai antibakteri yaitu dengan cara menyebabkan kebocoran protein dan enzim dari dalam sel bakteri E. coli (Madduluri et al., 2013). Saponin merupakan zat aktif yang dapat meningkatkan permeabilitas membran sehingga terjadi lisis pada sel. Apabila saponin berinteraksi dengan sel bakteri, bakteri tersebut akan pecah atau lisis (Poeloengan dan Praptiwi, 2010).

Uji kadar fenol dilakukan dengan menggunakan pereaksi Folin-Ciocalteau. Reagen Folin-Ciocalteau digunakan karena senyawa fenolik dapat bereaksi dengan Folin membentuk larutan berwarna yang dapat diukur absorbansinya pada panjang 
gelombang tertentu. Prinsip dari metode Folin-Ciocalteau adalah terbentuknya senyawa kompleks berwarna biru yang dapat diukur pada panjang gelombang 765 nm (Putri dkk., 2014).

Pada Tabel 6 menunjukkan bahwa kandungan kadar fenol asap cair tempurung kelapa sebesar 2,403\%. Gugus hidroksil senyawa fenol $(\mathrm{OH})$ berpengaruh terhadap aktivitas antibakteri dalam menghambat bakteri. Komponen senyawa fenol tanpa gugus hidroksil memiliki aktivitas antibakteri yang lebih tinggi karena dapat meningkatkan kemampuannya dalam mengikat membran lipid. Tingkatan dan banyaknya gugus fungsi hidroksil $(\mathrm{OH})$ pada golongan fenol berhubungan dengan tingkat toksisitasnya terhadap mikroorganisme, semakin meningkatnya proses hidroksilasi maka tingkat toksisitasnya juga semakin meningkat. Semakin tinggi senyawa fenol teroksidasi maka penghambatan pertumbuhan mikroorganisme akan semakin kuat (Cowan, 1999). Selain itu fenol dapat menyebabkan koagulasi protein, mengubah permeabilitas membran bakteri dan akhirnya sel membran mengalami lisis (mati) (Oliver et al., 2001).

Saponin dapat menurunkan tegangan permukaan air, sehingga akan mengakibatkan terbentuknya buih pada permukaan air setelah dikocok. Saponin merupakan steroid dan triterpen glikosida, dinamakan demikian karena sifatnya yang menyerupai sabun. Adanya unsur larut lemak (steroid atau triterpen) dan larut air pada satu molekul menyebabkan saponin memiliki sifat seperti deterjen (Anggraito dkk., 2018). Berdasarkan penelitian Akinpelu et al., (2014) saponin memiliki efek antioksidan dan antibakteri.

Pada penelitian dilakukan analisis kadar saponin pada asap cair tempurung kelapa dan diperoleh hasil yaitu sebesar $5,50 \%$. Hal ini menunjukkan selain kandungan kimia, masih ada zat kimia lain seperti saponin dalam asap cair tempurung kelapa. Informasi mengenai kandungan saponin dalam asap cair tempurung kelapa masih terbatas.

\section{KESIMPULAN}

Berdasarakan penelitian yang telah dilakukan, maka kesimpulan yang diperoleh yaitu:

1. Nilai $M I C$ asap cair tempurung kelapa yang mampu menghambat Escherichia coli adalah pada konsentrasi $10 \%$ dengan rata-rata diameter zona hambat sebesar 9,33 mm.

2. Asap cair tempurung kelapa mampu menghambat pertumbuhan bakteri $E$. coli secara in vitro yang ditandai dengan terbentuknya zona hambat pada konsentrasi $10 \%$ hingga $50 \%$.

3. Kandungan senyawa yang terdapat pada asap cair tempurung kelapa adalah fenol, flavonoid, triterpenoid, dan saponin, sedangkan untuk senyawa alkaloid tidak terkandung dalam asap cair tempurung kelapa. Selain itu, kadar fenol pada asap cair tempurung kelapa yaitu 2,403\% dan kadar saponin yaitu 5,50\%.

\section{DAFTAR PUSTAKA}

Akinpelu, B.A., Igbeneghu, O.A., Awotunde, A.I, Iwalewa E.O., and Oyedapo, O.O. 2014. Antioxidant and Antibacretial Activities of Saponin Fractions of Erythropheleum suaveolens (Guill and Perri) Stem Bark Extract. Science Research Essays 18 (9): 826-833.

Amalia, A., Sari, I., dan Nursanty, R. 2017. Aktivitas Antibakteri Ekstrak Etil Asetat Daun Sembung (Blumea balsamifera (L.) Dc.) Terhadap Pertumbuhan Bakteri Methicillin Resistant Staphylococcus aureus (MRSA). Prosiding Seminar Nasional Biotik. 5 (1): 387-391.

Anggraini, W., Nisa, S.C., Ramadhani, R.D.A., dan Ma'arif, B.Z.A. 2019. Aktivitas Antibakteri Ekstrak Etanol 96\% Buah Blewah (Cucumis melo L. var. cantalupensis) Terhadap 
Pertumbuhan Bakteri Escherichia coli. Pharmaceutical Journal of Indonesia. 5 (1): 61-66.

Anggraito, Y.U., Susanti, R., Iswari, R.S., Yuniastuti, A., Lisdiana, Nugrahaningsih, W.H., Habibah, N.A., dan Bintari, S.H. 2018. Metabolit Sekunder dari Tanaman Aplikasi dan Produksi. Fakultas Matematika dan Ilmu Pengetahuan Alam. Universitas Negeri Semarang. Semarang.

Bakti, I.A.R., Untari, B., dan Anugrah, D. 2002. Telaah Penggunaan Senyawa Aktif Hasil Pirolisis Tempurung Kelapa Untuk Pembasmi Bakteri Perusak Kayu (Bacillus cereus var mycoides). Jurnal Penelitian Sains. 11 : 52-61.

Cowan, M.M. 1999. Plants Products as Antimicrobial Agents. Clinical Microbiology Review 12 (4): 564-582.

Davidson, P.M., Sofos, J.N., Branen, A.L. 2005. Antimicrobials in Food. Third Edition. Taylor and Francis Group, CRC Press, Boca Raton.

Dewi, R., Nurliana, dan Jamin, F. 2013. Aktivitas Antibakteri Ekstrak Protein Crude Isi Saluran Pencernaan Ayam Broiler yang diberi Pakan Tambahan Pliek U. Jurnal Medika Veterinaria. 7 (1): 54-56.

Dian, R., Fatimawali, dan Budiarso, F. 2015. Uji Resistensi Bakteri Escherichia coli yang Diisolasi dari Plak Gigi Terhadap Merkuri dan Antibiotik Kloramfenikol. Jurnal $e$ Biomedik. 3 (1): 59-63.

Djoronga, M.I., Pandiangan, D., Kandou, F.E.F., dan Tangapo, A.M. 2014. Penapisan Alkaloid Pada Tumbuhan Paku dari Halmahera Utara. Jurnal MIPA Unsrat Online. 3 (2): 102-107.

Fiana, F.M., Kiromah, N.Z.W., dan Purwanti, E. 2020. Aktivitas Antibakteri Ekstrak Etanol Daun Sukun (Artocarpus altilis) terhadap Bakteri Staphylococcus aureus dan Escherichia coli. STIKES Muhammadiyah Gombong. Gombong.
Gemmel, C.G. and Lorian, V. 1996. Effects of Low Concentration of Antibiotics on Bacterial Ultrastructure, Virulence, and Suscebtability to Immunodefence: Clinical Significance. Di dalam Andrew, M.J.E. dan Russel, A.D, editor. The Revival of Injured Microbes. Academic Press.

Gilbert, P. 1984. The Revival of Microorganism Sublethally Injured by Chemical Inhibitors. Di dalam Andrew, M.J.E. dan Russel, A.D, editor. The Revival of Injured Microbes. Academic Press.

Goodman dan Gilman. 2007. Dasar Farmakologi Terapi, Edisi 10, Vol.2, 48: 1247-1253, Diterjemahkan oleh Tim Alih Bahasa Sekolah Farmasi ITB. Penerbit Buku Kedokteran. Jakarta.

Harini, N. dan Wachid, M. 2012. Pengembangan Bahan Pengawet Alami Asap Cair (Liquid Smoke) sebagai Senyawa Anti Bakteri. PBP. UMM. Malang.

Hidayat, T. dan Qomaruddin. 2015. Analisa Pengaruh Temperatur Pirolisis dan Bahan Biomassa Terhadap Kapasitas Hasil Pada Alat Pembuat Asap Cair. Fakultas Teknik. Universitas Muria Kudus. Kudus.

Ikalinus, R., Widyastuti, S.K., dan Setiasih, N.L.E. 2015. Skrining Fitokimia Ekstrak Etanol Kulit Batang Kelor (Moringa oleifera). Indonesia Medicus Veterinus. 4 (1): 71-79.

Indahyani, T. 2011. Pemanfaatan Limbah Sabut Kelapa Pada Perencanaan Interior dan Furniture yang Berdampak Pada Pemberdayaan Masyarakat Miskin. Humaniora. 2 (1): 15-17.

Jayanudin, Suhendi, E., Uyun, J., Supriatna, A.H. 2012. Pengaruh Suhu Pirolisis dan Ukuran Tempurung Kelapa Terhadap Rendemen dan Karakteristik Asap Cair Sebagai Pengawet Alami. Fakultas Teknik. Universitas Sultan Ageng Tirtayasa. Banten.

Karseno, Darmadji, P., Rahayu, K. 2002. Daya Hambat Asap Cair Kayu Karet 
Terhadap Bakteri Pengkontaminan Lateks dan Ribbed Smoke Sheet. Agritech. 21 (1): 10-15.

Laia, H.C.G., Yusliana, Daeli, P.J., Sarwendah, dan Chiuman, L. 2019. Uji Antibakteri Air Perasan Daging Buah Nanas (Ananas comosus (L) Merr) terhadap Bakteri Staphylococcus aureus. Jurnal Kedokteran dan Kesehatan. 15 (2): 170-177.

Madduluri, S., Rao, K.B., and Sitaram, B. 2013. In Vitro Evaluation of Antibacterial Activity of Five Indigenous Plants Extract Against Five Bacterial Pathogens of Human. International Journal of Pharmaceutical Sciences. 5 (4): 679684.

Manongko, P.S., Sangi, M.S., dan Momuat, L.I. 2020. Uji Senyawa Fitokimia dan Aktivitas Antioksidan Tanaman Patah Tulang (Euphorbia tirucalli L.). Jurnal Mipa. 9 (2): 64-69.

Masthura dan Zulkarnain. 2018. Karakterisasi Mikrostruktur Karbon Aktif Tempurung Kelapa dan Kayu Bakau. Journal of Islamic Science and Technology. 4 (1): 45-54.

Mpila, D.A., Fatimawali, dan Wiyono, W.I. 2012. Uji Aktivitas Antibakteri Ekstrak Etanol Daun Mayana (Coleus atropurpureus [L] Benth) Terhadap Staphylococcus aureus, Escherichia coli dan Pseudomonas aeruginosa Secara In-Vitro. Program Studi Farmasi FMIPA UNSRAT. Manado.

Muratore, G. and Licciardello, F. 2005. Effect of Vacuum and Modified Atmosphere Packaging on The ShelfLife of Liquid-Smoked Swordfish (Xiphias gladius) Slices. J Food Sci. 70:359-363.

Muzafri, A. 2019. Uji Aktivitas Antimikroba Ekstrak Andaliman (Zanthoxylum acanthopodium DC.) Pada Staphylococus aureus. Jurnal Sungkai. 7 (1): 122-126.

Nadifah, F., Bhoga, M.Y, Prasetyaningsih, Y. 2014. Kontaminasi Bakteri Pada Saus Tomat Mie Ayam di Pasar
Condong Catur Sleman Yogyakarta Tahun 2013. Biogenesis. 2(1): 30-33.

Nasruddin. 2015. Karakteristik Asap Cair yang Ditambahkan Ekstrak Aroma Daun Pandan Wangi (Pandanus amaryllifolius Roxb.) Jurnal Dinamika Penelitian Industri. 26 (1): 19-31.

Nuria, M.C., Faizatun, A., dan Sumantri. 2009. Uji Aktivitas Antibakteri Ekstrak Etanol Daun Jarak Pagar (Jatropha curcas L.) Terhadap Bakteri Staphylococcus aureus ATCC 25293, Escherichia coli ATCC 25922, dan Salmonella typhi ATCC 1408. Jurnal Ilmu Pertanian. 5 (2): 26-37.

Nurwanto. 2007. Tata laksana Higiene Hidangan, Keracunan Hidangan dan Jenis Bakteri. http://www.ihsmakassar.com. Diakses pada tanggal 20 November 2020.

Oliver, S.P., Gillespie, B.E., Lewis, M.J., Ivey, S.J., Almeida, R.A., Luther, D.A., Johnson, D.L., Lamar, K.C., Moorehead, H.D., and Dowlen, H.H. 2001. Efficacy of A New Premilking Teat Disinfectant Containing A Phenolic Combination for The Prevention of Mastitis. J. Dairy Sci. 84 (6): 1545-1549.

Oroh, S.B., Kandou, F.E.F., Pelealu, J., dan Pandiangan, D. 2015. Uji Daya Hambat Ekstrak Metanol Selaginella delicatula dan Diplazium dilatatum Terhadap Bakteri Staphylococcus aureus dan Escherichia coli. Biologi FMIPA Universitas Sam Ratulangi Manado. Manado.

Paju N., Yamlean, P.V., dan Kojong, N. 2013. Uji Efektivitas Salep Ekstrak Daun Binahong (Anredera cordifolia Steenis.) pada Kelinci Oryctolagus cuniculus) yang Terinfeksi Bakteri Staphylococcus aureus. Pharmacon. 2 (1): 51-61.

Pasaribu, T., Astuti, D.A., Wina, E., Sumiati, and Setiyono, A. 2014. Saponin Content of Sapindus rarak Pericarp Affected by Particle Size and Type of Solvent, its Biological Activity on Eimeria tenella Oocysts. 
International Journal of Poultry Science. 13 (6): 347-352.

Poeloengan, M. dan Praptiwi. 2010. Uji Aktivitas Antibakteri Ekstrak Kulit Buah Manggis (Garcinia mangostana Linn). Media Litbang Kesehatan. 20 (2): 65-69.

Puteri, T. dan Milanda, T. 2017. Uji Daya Hambat Ekstrak Daun Lidah Buaya (Aloe vera L.) Terhadap Bakteri Escherichia coli dan Staphylococcus aureus. Farmaka. 14 (2): 9-17.

Putri, H.D., Sumpono, dan Nurhamidah. 2018. Uji Aktivitas Asap Cair Cangkang Buah Karet (Hevea brassilliensis) dan Aplikasinya dalam Penghambatan Ketengikan Daging Sapi. Jurnal Pendidikan dan Ilmu Kimia. 2 (2): 97-105.

Putri, D.D., Nurmagustina, D.E., dan Chandra, A.A. 2014. Kandungan Total Fenol dan Aktivitas Antibakteri Kelopak Buah Rosela Merah dan Ungu Sebagai Kandidat Feed Additive Alami Pada Broiler. Jurnal Penelitian Pertanian Terapan. 14 (3): 174-180.

Radji, M. 2011. Mikrbiologi. Buku Kedokteran. ECG. Jakarta.

Sari, E.M., Maruf, W.F., dan Sumardianto. 2014. Kajian Senyawa Bioaktif Ekstrak Teripang Hitam (Holothuria edulis) Basah dan Kering Sebagai Antibakteri Alami. Jurnal Pengolahan dan Bioteknologi Hasil Perikanan. 3 (4): 16-24.

Schlegel dan Schmidt. 1994. Mikrobiologi Umum. Gadjah Mada University Press. Yogyakarta.

Septiani, E.N., Dewi, dan Wijayanti, I. 2017. Aktivitas Antibakteri Ekstrak Lamun (Cymodocea rotundata) Terhadap Bakteri Staphylococcus aureus dan Escherichia coli. Saintek Perikanan. 13 (1): 1-6.

Slamet, S. dan Hidayat, T. 2015. Studi Eksperimen Pemilihan Biomassa Untuk Memproduksi Gas Asap Cair (Liquid Smoke Gases) Sebagai Bahan Pengawet. Jurnal Simetris. 6 (1): 3037.
Soleha, T.U. 2015. Uji Kepekaan Terhadap Antibiotik. Jurnal Kedokteran Universitas Lampung. 5 (9): 119-123.

Sutiknowati, L.I. 2016. Bioindikator Pencemar, Bakteri Escherichia coli. Jurnal Oseana. 40 (4): 63-71.

Susanti, A. 2006. Daya Antibakteri Ekstrak Etanol Daun Beluntas (Pluchea indicaless) Terhadap Escherichia coli Secara In Vitro. Fakultas Kedokteran Hewan UNAIR. Surabaya.

Wahyuningsih, N. 2017. Analisis Antibakteri Talinum triangulare Terhadap Staphylococcus aureus dan Escherichia coli. Skripsi. Fakultas Tarbiyah dan Keguruan. Universitas Islam Negeri Raden Intan.

Zuraida, I., Hasbullah, R., Sukarno, Budijanto, Prabawati, S., dan Setiadjit. 2009. Aktivitas Antibakteri Asap Cair dan Daya Awetnya Terhadap Bakso Ikan. Jurnal Ilmu Pertanian Indonesia. 14 (1): 41-4 